\title{
ON THE PROBLEM WHETHER THE INTESTINAL MOTILITY IS OF A NEUROGENIC OR MYOGENIC NATURE
}

\author{
Takesi Hukuhara, Sosogu Nakayama \\ AND Hiroyuki FUKUdA \\ Department of Physiology, Okayama University Medical School, Okayama
}

MAGNUS $^{9)}$ (1904) was the first who considered the intramural ganglion cells in relation to the origin of the intestinal motility. He found that a muscle strip containing ganglion cells contracted rhythmically, while a strip devoid of the cells remained motionless. On the basis of these results he put forward the neurogenic theory, in which the origin of rhythmic contractions of the small intestine was attributed to the ganglion cells residing in AuERBAch's plexus. However, all the investigators who repeated the MAGNUs' experiments could not confirm his results but found that the cell-free muscle strip was able to contract rhythmically as well (GUNN and UNDERHILL ${ }^{6)}$ (1914); ALvAREZ and MAHONEY ${ }^{13}$ (1922); GASSER ${ }^{5)}$ (1926); VAN EsvelD ${ }^{3)}$ (1928) and Evans and SCHILD $^{4)}$ (1953)). These investigators thus, except for VAN ESVELD, postulated the myogenic theory, in which the muscle was considered as endowed with an inherent ability to contract. VAN ESVELD was reluctant to support the myogenic theory for the reason that in the cell-free muscle strip, there still remained a number of interstitial cells, which, at that time, was regarded as possible primitive nerve elements. However, his reservation on this point may be rejected since the recent electronmicroscopic study revealed that these cells were not primitive nerve cells but connective tissue elements (RICHARDSON ${ }^{10}$, 1958).

Although the results so far obtained seem to favor the myogenic theory, the present authors consider it too hasty a conclusion because the cell-free strip still contains the axons of ganglion cells, which might produce the substance to stimulate the intestinal muscle to contract. It is evident that the terms 'cell free' and 'cell containing' are erroneous but for the convenience sake the present authors retain the term 'cell' to denote the cell body. In order to solve this question the present experiments were carried out.

Received for publication May 7, 1965

福原 武, 中山 沃, 福田博之 


\section{METHODS}

Dogs weighing 6-13 kg were anesthetized by the intravenous injection of pentobarbital sodium $(20 \mathrm{mg} / \mathrm{kg})$, and the abdominal cavity was then opened with the mid-line incision to remove the duodenal loop of about $5 \mathrm{~cm}$ in length, the cavity of which was opened by a longitudinal incision through the wall along its mesenteric border. The loop was then cut into two pieces, the one $4 \mathrm{~cm}$ and the other $1 \mathrm{~cm}$ in length, the former being preserved in Tyrode solution at $1-4^{\circ} \mathrm{C}$ for further experiments. The latter was immersed into cooled Tyrode solution which was kept at about $4^{\circ} \mathrm{C}$, and spread out by pinning the edges with the mucosal surface upwards on a cork plate. The submucosa together with mucosa was then stripped off the piece. The two kinds of preparations, 'ganglion-cell containing' and 'cell-free', were obtained from this piece, which consisted of the two outer muscle layers and AUERBACH's plexus. The former preparation was obtained by cutting the piece into strips about $20 \mathrm{~mm}$ long and $1.5-2$ $\mathrm{mm}$ wide along the direction of the circular muscle with a safety-razor blade. The latter preparation was a bundle of circular muscles stripped off the piece as follows: Under the dissecting microscope the circular muscle of $1.5-2 \mathrm{~mm}$ in width was gripped at the region close to its cut end with a small forceps and then quietly stripped off to obtain the preparation of about $20 \mathrm{~mm}$ in length, care being taken to leave the undermost layer of the circular muscle untouched in order to ensure complete absence of 'nerve cells' in the preparation.

In the course of the experiments it was found quite unexpectedly that, if the longitudinal muscle layer was carefully stripped off with a forceps Auerbach's plexus did not adhere to the longitudinal muscle layer but remained to the circular muscle layer. Thus, it became possible to obtain 'cell-containing' circular muscle strip and 'cell-free' longitudinal muscle strip.

Both the 'cell-containing' and 'cell-free' preparations were also prepared from the intestine cooled $1-4^{\circ} \mathrm{C}$ for $12-24$ hours, procedures being the same as described above.

Preparations free from all the intramural nervous elements were obtained as follows: The jejunal loop of $25 \mathrm{~cm}$ in length was isolated as THIRY-Vella loop which had previously been denervated and whose intramural ganglion cells had been destroyed by the complete anemia method described by Hukuhara, Sumi and Kotani ${ }^{7}$ (1961) and Hukuhara, Kotani and SATO ${ }^{8)}$ (1962). Two weeks after the operation the preparations consisted of the longitudinal and circular muscle layers and degenerated Auerbach's plexus were prepared.

Preparations were suspended in the bath filled with $100 \mathrm{ml}$ Tyrode solution, which was bubbled with oxygen gas and whose temperature was kept constant at $37^{\circ} \mathrm{C}$. The Tyrode solution was modified after TAKEMASA ${ }^{13,14)}$ (1957) as follows: $0.221 \mathrm{M}-\mathrm{NaCl}$,

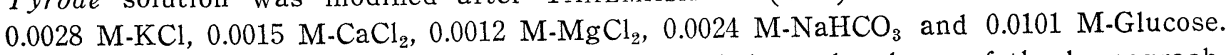
The contractions of the preparations were recorded on the drum of the kymograph, the preparations being given the tension of 1 to $1.5 \mathrm{~g}$.

After the termination of the experiments all the preparations were stained supravitally with methylenblue to determine whether they contained ganglion cells or not: The preparations were spread out on a plate, soaked with a staining solution consisted of $8.0 \mathrm{~g} \mathrm{NaCl}, 0.3 \mathrm{~g}$ resorcine, $0.3 \mathrm{~g}$ methylenblue and $1000 \mathrm{ml}$ distilled water (ScHABA$\mathrm{DASCH}^{11)}, 1930$ ) and observed under the dissecting microscope with the magnification ranging from 8 to 60 times. The room temperature was ranged from $25-28^{\circ} \mathrm{C}$.

Drugs used were physostigmine sulfate $(M e r c k)$, acetylcholine hydrochloride (Daiichi Seiyaku), atropine sulfate (Tanabe Seiyaku) and nicotine bitartrate (Katayama Kagaku). They were dissolved in the distilled water, care being taken not to add 
more than one $\mathrm{ml}$ of these solutions to avoid the effect of dilution of the Tyrode solution.

\section{RESULTS}

I. a) The 'cell-containing' preparations, irrespective of the different way of the preparation, behaved similarly as follows: They began to contract rhythmically 3 to 20 minutes after it was transferred to the bath fluid. The individual contraction was weak during the first several minutes and then with the laspe of time became gradually more powerful with an increasing period which ranged from 4 to 9 seconds. This state was maintained for 2 or 3 hours until the end of the observation. The preparations cooled at $1-4{ }^{\circ} \mathrm{C}$ for about 20 hours also contracted as rhythmically and powerfully as the fresh preparations. Between the fresh and cooled preparations no significant difference was observed as to the length of time elapsed until the preparations started to contract after they were transferred to the bath. Examples are shown in FIG. 1.

A

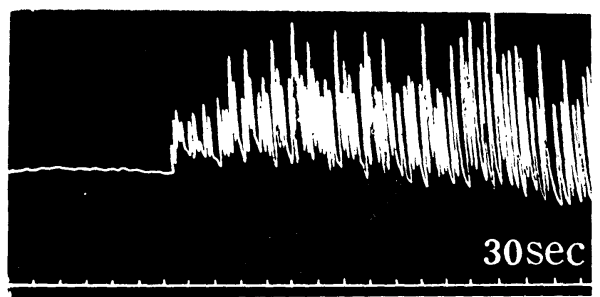

$\mathrm{B}$

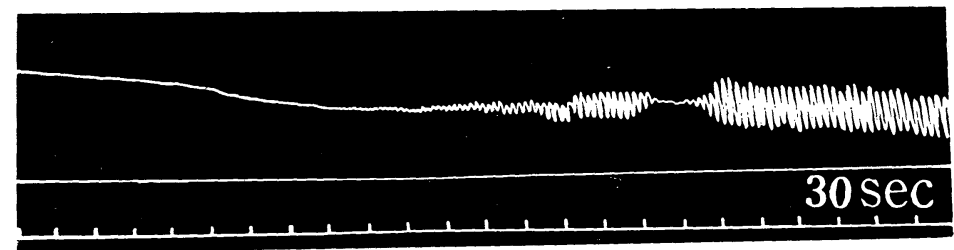

FIG. 1. Movements of ganglion-cell containing preparations. Muscle strip prepared from dog duodenum $20 \mathrm{~mm}$ long and $1.5 \mathrm{~mm}$ wide, consisting of the longitudinal and circular muscle layers. A : Fresh preparation. B : Preparation cooled at $1^{\circ} \mathrm{C}$ for 22 hours.

b) The ability of the 'cell-free' circular or longitudinal muscle preparations to contract rhythmically was much inferior to that of the 'cell-containing' preparations: Most of the preparations remained motionless (23 out of 27 preparations), and only a few contracted rhythmically (4 out of 27 preparations). In the latter cases the time elapsed until the contractions appeared was much longer than that observed in the 'cell-containing' preparations, and usually 30 minutes or longer. Individual contractions steadily increased in 


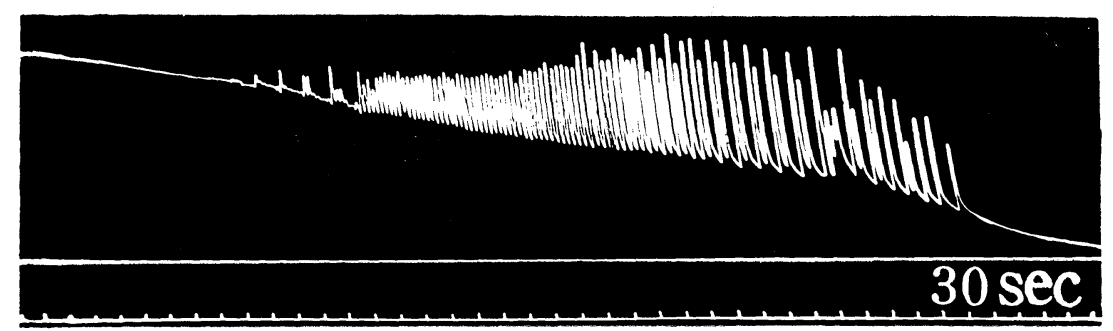

FIG. 2. Movements of a ganglion-cell free preparation. Circular muscle strip prepared from dog duodenum. No ganglion cell was detected by the supravital staining with methylenblue.

their amplitude, and the period of contractions also steadily increased as the time elapsed. It was characteristic that the contractions were abruptly abolished after they lasted for a relatively short time, usually for 30 minutes or so (FIG. 2).

The strips cooled at $1-4^{\circ} \mathrm{C}$ for about 20 hours behaved similarly to the fresh strips: Out of 15 cases, 10 preparations were motionless and 5 contracted. II. a) Rhythmic contractions observed in both the 'cell-containing' and ' cell-free' preparations were completely suppressed by adding atropine $10^{-4} \mathrm{~g} / \mathrm{ml}$ in the bath (FIG. 3).

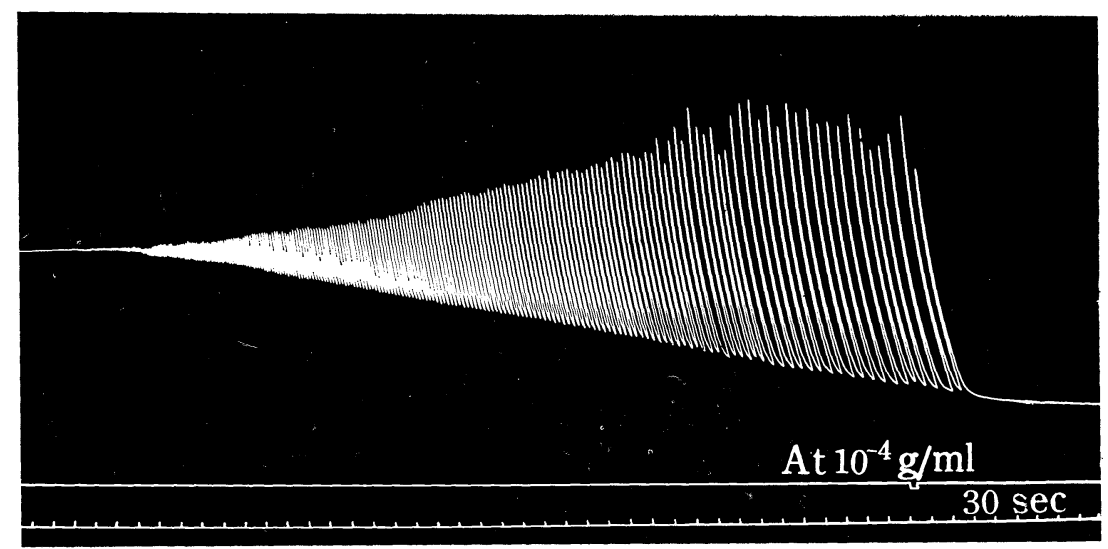

FIG. 3. Effect of atropine upon the motility of the ganglion-call containing preparation. Explanations are the same as in Fig. 1.

b) Physostigmine added to the bath at the concentration of $10^{-6} \mathrm{~g} / \mathrm{ml}$ had an excitatory effect on both the 'cell-containing' and 'cell-free' preparations. The tone of the muscle rose and the rhythmic contractions became powerful. Even the 'cell-free' preparations which remained motionless began to contract after the addition of the drug (FIG. 4). This induced contractions, however, disappeared again within 6-10 minutes. The excitatory effect of the drug was 


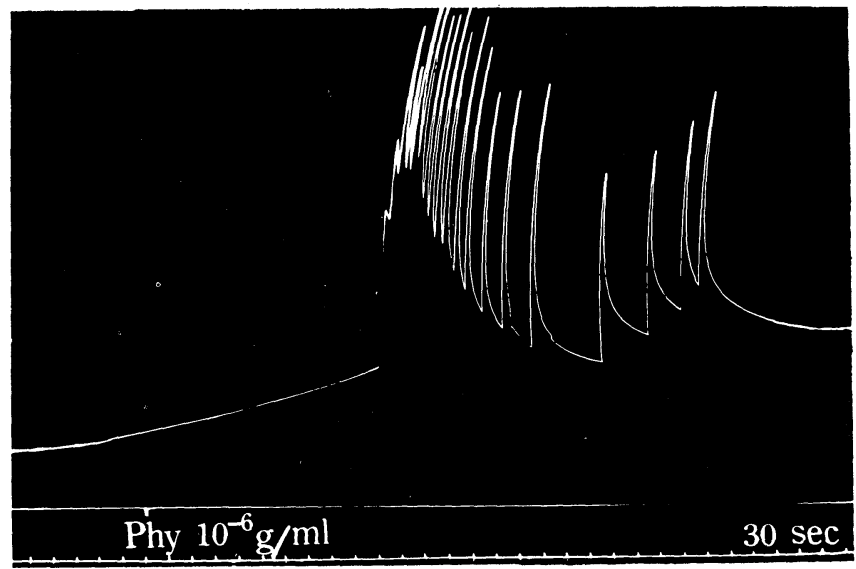

FIG. 4. Effect of physostigmine upon the motility of the ganglion cell-free preparation. Circular muscle strip prepared from dog duodenum.

completely suppressed by the administration of atropine.

In the cooled preparations the results were the same as those obtained in the fresh preparations.

c) In addition, acetylcholine always excited the intestinal motility of both the 'cell-containing' and 'cell-free' preparations, producing a rise of tone superimposed with rhythmic contractions. The threshold concentration of the drug was $10^{-10} \mathrm{~g} / \mathrm{ml}$ in fresh 'cell-containing' preparations and $10^{-8} \mathrm{~g} / \mathrm{ml}$ in fresh 'cell-free' preparations, while in the cooled intestine the threshold was a little higher, that is, $10^{-8} \mathrm{~g} / \mathrm{ml}$ in 'cell-containing' preparations and $10^{-7} \mathrm{~g} / \mathrm{ml}$ in 'cell-free' preparations.

III. Twenty muscle strips prepared from the aganglionic jejunal loops
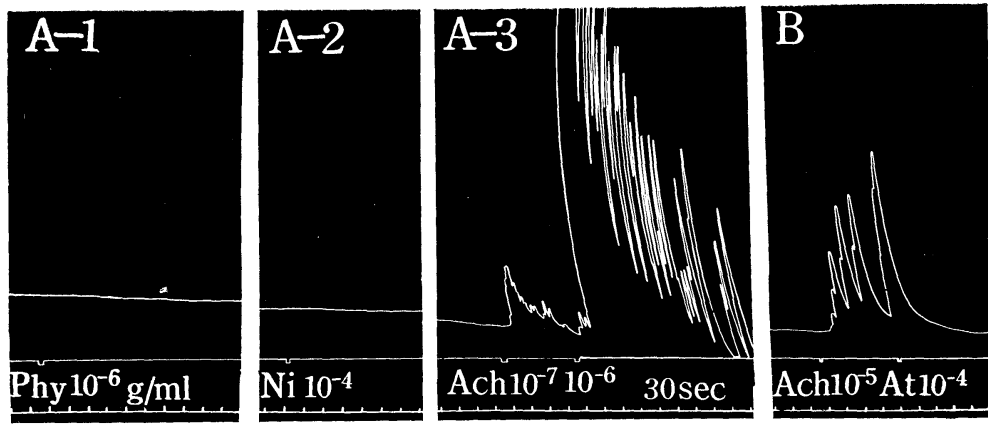

Fig. 5. Effects of some drugs on the muscle strips prepared from the aganglionic jejunal loop. A: The strip was motionless: physostigmine and nicotine were not effective (A-1 and -2), while acetylcholine produced powerful contractions (A-3). B: Another strip; the contractions produced by acetylcholine were completely suppressed by atropine. Time in $30 \mathrm{sec}$. 
showed no sign of the movement throughout the experiments lasting 3 hours or more. Physostigmine had no effect on the preparations, while acetylcholine had a remarkable influence (FIG. 5).

\section{DISCUSSIONS}

The results that both 'cell-containing' and 'cell-free' preparations show rhythmic contractions which can be suppressed with atropine and that the contractions are weaker (often non-existent) and shorter in duration in the latter preparation than in the former indicate that both preparations contain acetylcholine which elicits the contraction, but that its amount is less in the latter preparation. The acetylcholine seems to be produced continuously because the contraction in both preparations is excited by physostigmine, whose action can be suppressed by atropine. The experiments in which the strip was prepared from the intestine whose intramural nervous elements were selectively destroyed revealed that the site of production of acetylcholine resides in the nervous elements. Judging from the results described above, it is most probable that not only the cell bodies of the intramural ganglion cells but also their axons take part in the production of acetylcholine. In this connection, it may be pertinent to cite DikshiT' work $^{2)}$ (1933). He reported that acetylcholine was continuously released in the intestinal wall, and that AUERBACH's plexus-containing muscle contained much more acetylcholine than the plexusfree one. He further showed that not any trace of acetylcholine was found in the intestinal wall at an earlier stage of chick embryo, at which the intramural ganglion cell was not histologically ascertained, and concluded that AUERBACH's plexus was the site of production of acetylcholine. Furthermore SIINA ${ }^{12)}$ (1965) in our laboratory showed that the amount of acetylcholine contained in a loop whose intramural ganglion cells were selectively destroyed by means of the complete anemia method was much less than that estimated in a normal small intestine.

From our results and the considerations described above it may be concluded that the muscle stimulating substance, acetylcholine, is produced neurogenically, in other words, the automatic intestinal movement is of a neurogenic nature. The investigators who dwelt upon this subject paid too much attention to the cell bodies of ganglion cells, neglecting the axons and did not try to elucidate the relationship between the muscle stimulating substance and the structural elements of the intestinal wall.

Lastly it should be noted that on the aganglionic loop in vivo there could be observed incoordinated contractions (Hukuhara, Sumi and Kotani, ${ }^{7)}$ 1961). We are of the opinion that these contractions are considered to be triggered by acetylcholine which are produced in regions of the body other than the loop in question and transferred there by way of the blood stream. 


\section{SUMMARY}

1. On the dog small intestine the ganglion cell-containing muscle strip always rhythmically contracted, while the cell-free strip occasionally showed short lasting rhythmical contractions but in most cases remained motionless. And the muscle strip whose nervous elements has been previously destroyed by means of the complete anemia method was motionless throughout the experiment lasting for about 3 hours.

2. Physostigmine caused a rise of the intestinal tone superimposed with rhythmic contractions on both the ganglion cell-containing and -free strips, whereas the drug exerted no effect on the strip whose nervous elements were destroyed. 3 . The contractions observed in 1) and 2) were completely abolished by atropine. In addition, acetylcholine always exerted an excitatory effect on the motility of all kinds of muscle strips.

4. The evidences were thus obtained that the intramural ganglion cell, not only its cell body but also its axon, might be the site of production of acetylcholine which was responsible for maintaining the intestinal rhythmic contractions. The results thus suggest that the automatic movements of the small intestine may be of a neurogenic origin. ledged.

Financial support of the work by the Ministry of Education is gratefully acknow.

\section{REFERENCES}

1) Alvarez, W.C. and Mahoney, L. J. (1922). The myogenic nature of the rhythmic contractions of the intestine. Am. J. Physiol. 59: 421-430.

2) Dikshit, B. B. (1933). Acetylcholine formation by tissues. Quart. J. exp. Physiol. $28: 243-251$

3) van Esveld, L. W. (1928). Verhalten von plexushaltigen und plexusfreien Darmmuskelpräparaten. Naunyn-Schmiedebergs Arch. exp. Path u. Pharmak. 134: 347-386.

4) Evans, D.H. L. And Schild, H.O. (1953). The reactions of plexus-free circular muscle of cat jejunum to drugs. J. Physiol. 119: 376-399.

5) Gasser, H.S. (1926). Plexus-free preparations of the small intestine. A study of their rhythmicity and of their response to drugs. J. Pharmacol. $27: 395-410$.

6) Gunn, J.A. And Underhill, S. W. F. (1914). Experiments on the surviving mam. malian intestine. Quart. J. exp. Physiol. 8 : 275-296.

7) Hukuhara, T., Sumi, T. And Kotani, S. (1961). The role of the ganglion cells in the small intestine taken in the intestinal intrinsic reflex. Jap. J. Physiol. 11: 281-288.

8) Hukuhara, T., Kotani, S. And Sato, G. (1962). Comparative studies on the motility of the normal, denervated and aganglionic Thiry-loops. Jap. J. Physiol. 12: 348-356

9) Magnus, R. (1904). Die Beziehungen des Darmnervensystems zur automatischen Darmbewegung. Pflügers Arch. 102: 349-363. 
10) Richardson, K. C. (1958). Electronmicroscopic observations on Auerbach's plexus in the rabbit, with special reference to the problem of smooth muscle innervation. Am. J. Anat. 103: 99-122.

11) Schabadasch, A. (1930). Intramurale Nervengeflechte des Darmrohrs. Zeitschrift für Zellforschung, 10 : 320-385.

12) SirnA, H. (1965). The role of intramural ganglion cells taken in the acetylcholine formation. J. Physiol. Soc. Japan, 27, 270-278 (Japanese).

13) Takemasa, K. (1957). On the inorganic salt in the artificial nourishing fluid for isolated intestine. J. Physiol. Soc. Japan, 19:1217-1225 (Japanese).

14) Takemasa, K. (1957). On the buffer and oxygen supply in the artificial nourishing fluid for isolated intestine. J. Physiol. Soc. Japan, 19:1226-1233 (Japanese). 